Original research article

\title{
The knowledge of nurses on the disinfection of reusable objects and surfaces in clinical practice
}

\author{
Martin Krause ${ }^{1,2}$, František Dolák ${ }^{1}$, Marie Froňková ${ }^{2}$ \\ ${ }^{1}$ University of South Bohemia in České Budejovice, Faculty of Health and Social Sciences, Institute of Nursing, Midwifery and Emergency Care, \\ České Budějovice, Czech Republic \\ ${ }^{2}$ Technical University of Liberec, Faculty of Health Studies, Liberec, Czech Republic
}

\begin{abstract}
Introduction: Performing disinfection of reusable high-touch objects and surfaces is one of the important aspects in the prevention of healthcare-associated infections. It is also important for the quality and safe provision of medical services. Nurses should have the knowledge to perform mechanical cleaning and disinfection, and of disinfectants, including the range of effectiveness, preparation, and method of application of disinfectants.

Design: Cross-sectional quantitative research using a questionnaire.

Methods: Quantitative research using the questionnaire technique was used to determine the knowledge of nurses about the principles of mechanical cleaning and disinfection of repeatedly used non-critical objects and areas in clinical practice. The research group consisted of 184 nurses from a selected regional hospital in the Czech Republic. Respondents from standard internal medicine and surgical departments participated in the research. Data were analysed using descriptive statistics and a statistical test.

Results: The research found that $68.5 \%$ of nurses knew the procedure for the decontamination of work surfaces without the presence of biological material, and $51.1 \%$ of nurses knew the procedure for the decontamination of work trays with the presence of biological material. $51.1 \%$ of nurses were aware of the interpretation of the range of the effectiveness of disinfectants, and $65.2 \%$ of nurses were aware of the dilution of disinfectant solution.

Conclusions: Based on the results of the research, we can state that nurses have adequate knowledge in some areas, but even so, it is necessary to provide regular training in the principles of decontamination of selected objects and areas used in nursing practice. Infections associated with health care can be influenced by following established hygienic-epidemiological principles.
\end{abstract}

Keywords: Clinical practice; Disinfection; Knowledge; Nurse; Nursing

\section{Introduction}

When providing nursing care, nurses use a variety of objects and areas that are designed to be reused. The Decree of the Ministry of Health of the Czech Republic No. 306/2012 Coll. stipulates that repeatedly used medical devices are decontaminated for their further use (Act No. 306/2012 Coll.). In cases of insufficient decontamination, indirect transmission and subsequent development of healthcare-associated infections can occur (Matoušková and Jurásková, 2017). Transmission through contaminated hands or contact with contaminated surfaces accounts for approximately $20-40 \%$ of healthcare-associated infections (Suleyman et al., 2018). The problem areas are mainly objects and areas that are in frequent contact with the hands of health professionals, including nurses (Schmidt et al., 2016). These are mainly so-called high-touch objects and surfaces, i.e., objects which receive a high degree of touch (Link et al., 2016; Russotto et al., 2015). High-touch objects and surfaces require more attention and more frequent decontamination as they are involved in the transmission chain of microorganisms (Donskey, 2019). Examples of high-touch items include phonendoscopes, monitors, keyboards, medical records, mobile phones, and other medical devices (Russotto et al., 2015). They can also be medical devices intended for diagnostic and therapeutic purposes, objects for drug administration, wound care etc. (Krause and Dolák, 2020). Non-critical areas and surfaces may contribute to an increased risk of transmission of healthcare-associated infections (Russoto et al., 2015; Yang et al., 2017). For this reason, it is important to follow various hygienic-epidemiological measures, especially decontamination, to prevent the spread of pathogens associated with medical care (Sattar, 2016). The maintenance of objects and surfaces is a daily activity of a nurse (Wilson and Nayak, 2016). Nurses in the Czech Republic are able to perform disinfection of repeatedly used objects and surfaces by the Decree No. 55/2011 Coll.

\footnotetext{
* Corresponding author: Martin Krause, Technical University of Liberec, Faculty of Health Studies, Studentská 1402/2, 46117 Liberec 1, Czech Republic; e-mail: martin.krause@tul.cz http://doi.org/10.32725/kont.2021.008

Submitted: 2020-10-15 • Accepted: 2021-02-17 • Prepublished online: 2021-02-26 
Decontamination requires a certain procedure (World Health Organization, 2018a). One of the possibilities is the application of the Deming cycle, i.e., the consecutive phases of Plan, Do, Check and Act. This cycle can also represent a certain algorithm when performing decontamination. Spaulding's classification (World Health Organization, 2016) can be used to select adequate decontamination. In relation to the decontamination of reusable high-touch non-critical objects and surfaces, decontamination means mechanical cleaning and chemical disinfection (World Health Organization, 2018a). Furthermore, it is necessary to choose an adequate disinfectant with a prescribed range of effectiveness and suitable personal protective equipment (World Health Organization, 2018b). Regarding disinfection, it is important to choose a one-stage or two-stage procedure (Hedlová et al., 2014). An important aspect is the preparation of the solutions used as well as their dilution (World Health Organization, 2016). It is also important to appropriately apply disinfectants. Another part of the Deming cycle is checking the disinfection process, which is one of the necessary components for the continuous improvement of the quality of activities. The result or the disinfection process can be checked. The last part of the Deming cycle is negotiations, i.e., continuous improvement and the search for alternative methods (World Health Organization, 2016). An effective part is the education and training of nurses regarding decontamination (Luebbert and Chinnes, 2015). Simulation teaching methods are a significant possibility to ensure the quality of medical care provided to patients (Motola et al., 2013). Another major aspect is the search for new methods, such as antimicrobial surfaces using nanomaterials (Hasan and Chatterjee, 2015). It is important that nurses have knowledge regarding decontamination of objects and surfaces, especially regarding disinfection of reusable objects and surfaces. This is also based on the requirements of accreditation standards (Marx and Vlček, 2013). The aim of the research is to find out the level of knowledge of nurses regarding mechanical cleaning and chemical disinfection of reusable objects and surfaces.

\section{Materials and methods}

The research was carried out using a quantitative method and a self-developed questionnaire. At the beginning of the research, preliminary research was carried out, and based on the results of the preliminary research, the questionnaire was optimized and subsequently distributed. The construction of the questionnaire was based on the current state of relevant sources, including national and international recommendations, and the valid legislation of the Czech Republic. The questionnaire was anonymous, voluntary, and did not contain any controversial ethical issues. It contained a total of 18 questions, of which 5 questions were associated with identification and 13 questions were associated with research. The achieved knowledge was divided into 3 categories by points, i.e., advanced knowledge (75.0-100.0\%), intermediate knowledge (50.0-74.9\%), and insufficient knowledge (0.0-49.9\%). The research data were processed using descriptive statistics and evaluated by a statistical chi-square test (Pearson distribution) using TIBCO Statistica software, version 12. The determined level of significance was $\alpha=0.05$. First, the 1 st-degree classification was performed. Then statistical testing was performed to determine significant relationships. Data collection was carried out in a regional hospital from March to June 2020. The research was carried out with the consent of a selected medical care provider. The research results apply only to this research.

\section{The sample group of respondents}

The research group consisted of 184 general nurses who work in standard departments of internal medicine and surgery for the selected medical care provider. The selection of the research group was intentional, and three criteria were selected, which were the participation of only general nurses, the performance of professions in standard departments of internal medicine and surgery, and the implementation of nursing interventions that require chemical disinfection. The study involved 7 (3.8\%) men and 177 (96.2\%) women. The age of the respondents was between 40-49 years (37.0\%) Table 1. Another monitored area was the length of practice, where most respondents' length of practice was 21 and more years $(41.9 \%)$ - Table 2; 114 (62.0\%) respondents had secondary education, 28 (15.2\%) respondents had completed higher vocational education, 34 (18.5\%) respondents had a bachelor's degree, 7 (3.8\%) respondents had a master's degree and $1(0.5 \%)$ respondent had a doctoral degree. The research involved 90 (48.9\%) respondents from surgical disciplines and 94 (51.1\%) respondents from internal medicine disciplines.

\begin{tabular}{lcc} 
Table 1. Age of the respondents & \\
\hline$N=184$ & $n$ & $\%$ \\
\hline $20-29$ years & 37 & 20.1 \\
$30-39$ years & 45 & 24.4 \\
$40-49$ years & 68 & 37.0 \\
$50-59$ years & 23 & 12.5 \\
60 years and older & 11 & 6.0 \\
\hline
\end{tabular}

\section{Table 2. Length of practice of the respondents}

\begin{tabular}{lcc}
$N=184$ & $n$ & $\%$ \\
\hline $0-1$ year & 12 & 6.5 \\
$2-5$ years & 30 & 16.3 \\
$6-10$ years & 19 & 10.3 \\
$11-15$ years & 22 & 12.0 \\
$16-20$ years & 24 & 13.0 \\
21 years and more & 77 & 41.9 \\
\hline
\end{tabular}

\section{Results}

We were studying the knowledge of general nurses regarding disinfection. The knowledge was divided into several main areas.

When classifying the selected subject using the Spaulding classification, we found that, in most cases, nurses correctly classified selected subjects among critical, semi-critical, or non-critical subjects. Specifically, the phonendoscope is classified as a non-critical item, a tonometer is included in non-critical items, a urine bottle is included in non-critical items, tweezers for removing stitches was classified as a critical item, a sanitary sink was included in semi-critical items, and electrocardiograph leads were included in non-critical items (Table 3). 
Table 3. Classification of selected objects and areas according to Spaulding's classification

\begin{tabular}{lrccc}
$N=184$ & $\begin{array}{c}\text { Critical } \\
\text { objects } \\
(\%)\end{array}$ & $\begin{array}{c}\text { Semi- } \\
\text { critical } \\
\text { objects } \\
(\%)\end{array}$ & $\begin{array}{c}\text { Non- } \\
\text { critical } \\
\text { objects } \\
(\%)\end{array}$ & $\begin{array}{c}\text { N/A } \\
(\%)\end{array}$ \\
\hline Phonendoscope & 0.5 & 33.8 & 65.2 & 0.5 \\
Tonometer & 0.0 & 14.7 & 84.8 & 0.5 \\
Urine bottle & 12.0 & 63.0 & 23.9 & 1.1 \\
Tweezers for removing stitches & 90.2 & 9.3 & 0.5 & 0.0 \\
Sanitary sink & 4.3 & 52.2 & 43.5 & 0.0 \\
Electrocardiograph leads & 2.7 & 38.6 & 56.0 & 2.7 \\
\hline
\end{tabular}

Furthermore, the nurses' knowledge of the single-use symbol (displayed on the packaging or on the medical device) was also determined. For the single-use symbol (crossed-out number 2 in a circle), the majority of nurses (75.0\%) correctly stated that it was a medical device intended for single use only. On the contrary, the N/A option was marked by $20.2 \%$ of respondents.

Regarding mechanical cleaning and further disinfection, it was ascertained whether the nurses knew the reason for it. The main reason for performing mechanical cleaning is the removal of impurities and the physical reduction of the number of microorganisms. This was correctly stated by $85.9 \%$ of respondents. On the contrary, $4.9 \%$ of respondents believed that the reason for performing mechanical cleaning was the removal of bacteria, viruses, fungi, and spores. The reason for performing chemical disinfection is mainly the removal of veg- etative forms of microorganisms. This answer was correctly given by $18.5 \%$ of nurses. Some nurses believed (46.2\%) that chemical disinfection led to the removal of bacteria, viruses, fungi, and spores. $20.7 \%$ of nurses believed that they served to remove only pathogenic bacteria and some viruses and spores.

The decontamination procedure is different if there is a presence of biological material (such as blood) on the disinfected surface. The correct decontamination of a work tray that is stained with biological material is to perform disinfection first and then mechanical cleaning. More than half (51.1\%) of nurses know this procedure. However, $27.1 \%$ of nurses would first perform mechanical cleaning and then disinfection, and $10.9 \%$ of nurses would first perform disinfection and then a higher degree of disinfection. The correct procedure for decontamination of the work surface for the preparation of injection and infusion therapy without the presence of biological material is to perform mechanical cleaning first and then disinfection. This procedure would be performed correctly by $68.5 \%$ of nurses, but $19.0 \%$ of nurses would perform disinfection first and then mechanical cleaning. $2.2 \%$ of respondents chose to perform mechanical cleaning first and then two-stage disinfection. $8.1 \%$ of nurses chose the option of first performing disinfection and then performing a higher degree of disinfection. The N/A option was chosen by $2.2 \%$ of nurses.

The research also focused on which method of highest-level decontamination nurses would use after using the leads of an electrocardiograph, bronchoscope, laryngoscopic spoon, and surgical tweezers. The nurses were supposed to choose the option that chemical disinfection was the method of highest-level decontamination for electrocardiograph leads, a higher degree of disinfection for bronchoscopy, two-stage disinfection for a laryngoscopic spoon, and sterilization decontamination for surgical forceps (Table 4).

Table 4. The highest-level decontamination of selected medical tools

\begin{tabular}{|c|c|c|c|c|c|}
\hline$N=184$ & $\begin{array}{c}\text { Disinfection } \\
(\%)\end{array}$ & $\begin{array}{l}\text { Higher-level } \\
\text { disinfection } \\
(\%)\end{array}$ & $\begin{array}{c}\text { Two-stage } \\
\text { disinfection } \\
(\%)\end{array}$ & $\begin{array}{c}\text { Sterilization } \\
(\%)\end{array}$ & $\begin{array}{l}\text { N/A } \\
(\%)\end{array}$ \\
\hline Electrocardiograph leads & 83.2 & 6.5 & 2.7 & 0.0 & 7.6 \\
\hline Bronchoscope & 2.2 & 28.8 & 34.2 & 25.0 & 9.8 \\
\hline Laryngoscopic spoon & 3.3 & 6.0 & 23.9 & 57.0 & 9.8 \\
\hline Surgical tweezers & 0.5 & 0.5 & 1.1 & 93.5 & 4.4 \\
\hline
\end{tabular}

Regarding the choice of disinfectant, its range of effectiveness (which is stated on the product packaging) is also decisive. Knowledge of the range of effectiveness is therefore also important. The correct range of effectiveness was assigned to individual labels by $51.1 \%$ of nurses, namely A (bactericidal), B (virucidal), and C (sporicidal). $20.7 \%$ of nurses stated that the letter A indicates sporicidal activity, B bactericidal activity, and $C$ virucidal activity. $9.2 \%$ of respondents stated that the letter $\mathrm{A}$ indicates fungicidal activity, $\mathrm{B}$ bactericidal, and $\mathrm{C}$ tuberculocidal. $17.4 \%$ of nurses chose the N/A option.

Another area of the research was focused on the preparation and use of disinfectants. Nurses were to determine the quantity of water and disinfectant that they would use to prepare 8 litres of $0.5 \%$ solution. The correct option is $40 \mathrm{ml}$ of disinfection and 7,960 $\mathrm{ml}$ of water, which was correctly determined by $65.2 \%$ of nurses. The option of $20 \mathrm{ml}$ of disinfection and $7,980 \mathrm{ml}$ of water was chosen by $8.7 \%$ of nurses, the option of $60 \mathrm{ml}$ of disinfection and 7,940 $\mathrm{ml}$ of water was chosen by $3.8 \%$ of nurses, and the option of $100 \mathrm{ml}$ of disinfection and $7,900 \mathrm{ml}$ of water was chosen by $3.3 \% ; 19.0 \%$ of nurses chose the N/A option. Also, nurses were to choose the correct procedure for diluting the disinfectant solution. It is important to first fill a container with water and then add disinfectant; $79.9 \%$ of nurses would perform this procedure correctly; $9.8 \%$ of nurses would choose the opposite procedure, i.e., fill the container with disinfectant first and then add water. The same number of nurses $(9.8 \%)$ would fill the container with water and disinfectant at the same time. The answer N/A was marked by $0.5 \%$ of respondents. According to the valid legislation of the Czech Republic, the diluted disinfectant should be used for 8-12 hours; $50.0 \%$ of the nurses were aware of this fact. The diluted disinfectant would be used for a maximum of 4-6 hours by $26.6 \%$ of nurses, $16-24$ hours by $16.3 \%$ of nurses, $32-48$ hours by $1.1 \%$ of nurses, and $6.0 \%$ of nurses chose the N/A option.

It is important to maintain a minimum exposure time for disinfection to be effective. We wanted to find out the level of knowledge of the minimum exposure time of a selected and 
frequently used alcohol disinfectant (the prescribed exposure time of 30 seconds). The selected disinfectant would be left to work properly by $41.3 \%$ of nurses. The exposure time of 5 seconds was chosen by $3.8 \%$ of nurses, 10 seconds by $8.2 \%$ of nurses, 20 seconds by $4.3 \%$ of nurses, 60 seconds by $36.4 \%$ of nurses, and the N/A option was chosen by $6.0 \%$ of nurses.

The research was also focused on an important aspect of health and safety at work, i.e., first aid in case of contact with the eyes of the most frequently used disinfectant. In case of contact with the eyes, according to the manufacturer's instructions, it is important to rinse the eyes with clean running water with the eyelids open for at least 10 minutes. This option was correctly stated by $45.1 \%$ of nurses. On the contrary, the same procedure, but only for 5 minutes, was chosen by $40.8 \%$ of nurses. A minimum number of respondents stated that rinsing should be performed with eye water for at least 5 minutes $(10.3 \%)$ or 10 minutes ( $2.7 \%$ of respondents); $1.1 \%$ of respondents chose the N/A option.

Based on the statistical evaluation of the variables, it was found that a statistically significant relationship ( $\alpha=0.05)$ was achieved between the achieved knowledge and education, age, and workplace. On the contrary, it was not possible to prove a statistically significant relationship between the achieved knowledge and the length of practice (Table 5). The results showed that nurses working in internal medicine have lower knowledge of performing disinfection of objects and surfaces than nurses working surgery. It was also found that nurses with a university degree, a length of experience of 11-15 years, and who are in the age category of 30-39 years have higher knowledge.

Table 5. Statistical evaluation of achieved knowledge depending on variables

\begin{tabular}{lcc} 
& $p$-value & $C \mathrm{p}$ \\
\hline Knowledge by education & 0.004 & 0.278 \\
Knowledge by length of practice & 0.115 & 0.279 \\
Knowledge by age & 0.005 & 0.303 \\
Knowledge by workplace & $<0.001$ & 0.379 \\
\hline
\end{tabular}

\section{Discussion}

Florence Nightingale said that educating nurses in infection prevention is a key area for a professional career. At that time, infections were somewhat neglected, and the cleanliness of the environment and clean air were the only protection that the nurse herself could provide (Nightingale, 1859). At present, a number of preventive measures already exist, and one of the basic measures in the prevention of not only healthcare-associated infections is decontamination. Decontamination of reusable objects and surfaces is one of the basic activities of nurses regarding the provision of safe and quality care. It is important to follow a procedure for decontamination (Wilson and Nayak, 2016). The already mentioned Deming cycle can be used for this (World Health Organization, 2016). The implementation of decontamination entails the need for nurses to have the knowledge and apply it in the implementation of decontamination in clinical practice - as a large part of healthcare-associated infections is preventable. As part of the research with the questionnaire survey technique, we determined the knowledge of nurses about the principles of decontamination of repeatedly used high-touch objects and surfaces. The results of the research are unsettling in some areas. How- ever, it is important to note that, in this research, we detected clinically relevant areas for establishing training and possibly further education of nurses regarding decontamination.

One of the basic components of reusable objects and surfaces is the knowledge of determining the method of decontamination with the possible use of Spaulding's classification. Thus, sterilization should be performed on critical items, twostage disinfection on semi-critical items, and chemical disinfection on non-critical items (Hedlová et al., 2014; World Health Organization, 2018a). This research found that nurses could recognize some items using Spaulding's classification, i.e., a tonometer is a non-critical item (84.8\%) and tweezers designed to remove stitches are a critical item (90.2\%). However, it was found that only $65.2 \%$ of nurses included the phonendoscope in non-critical items, $52.2 \%$ of nurses correctly classified the washbasin for hygienic care as a semi-critical item, and only $56.0 \%$ of nurses correctly classified electrocardiograph leads as a non-critical item, which was not an optimal finding. Nurses often may be unaware of the risk that the medical devices they use in practice on a daily basis may be potential infection agent storage, and involved in the transmission of a variety of infections. However, this classification is important in determining how reusable medical devices should be decontaminated to ensure their safety for further use (World Health Organization, 2018a). We can mention that lower knowledge may be related to the fact that the training may not be focused on current issues (including Spaulding's classification) using available and effective resources.

Interesting findings were raised by the questions regarding the reason for performing mechanical cleaning and chemical disinfection. Mechanical cleaning leads to the removal of impurities deposited on an inanimate object or surface, and it also prevents the formation of a biofilm (World Health Organization, 2016). The Royal College of Nursing mentions that cleaning is a critical element in the decontamination process and should be performed in all circumstances, regardless of the required level of decontamination (Royal College of Nursing, 2017). Most respondents were aware of the reason for performing mechanical cleaning, but the awareness of the reason for performing chemical disinfection was very low. Almost half of the nurses believed that chemical disinfection could remove bacteria, viruses, and fungi, including all spores, or that chemical disinfection only served to remove pathogenic bacteria. The basic characteristics are based on Act No. 258/2000 Coll. This finding is important for establishing and optimizing training regarding performing decontamination of objects and surfaces. At the same time, it is important to respect the conditions set by the manufacturer and the conditions specified in the internal regulations of the health service provider.

Another problematic aspect is the procedure for decontamination of a work tray that is stained with biological material. The valid legislation of the Czech Republic states that in order to perform decontamination with the presence of biological material, it is necessary to first perform disinfection and then mechanical cleaning (Act No. 306/2012 Coll.). However, only half of the respondents chose this option. Failure to follow this procedure may result in a health hazard to medical professionals. On the contrary, several nurses (68.5\%) mentioned the correct procedure for decontamination of the work surface without the presence of biological material. They first performed mechanical cleaning and then disinfection. If disinfection is not performed adequately, microorganisms may persist on objects and surfaces for several days to several months (Russotto et al., 2015). For this, we can recommend using illustrative materials for decontamination of objects and surfaces. 
We also found that nurses may have difficulty distinguishing basic terms, i.e., two-stage disinfection and a higher degree of disinfection. These terms are again based on the valid legislation of the Czech Republic (Act No. 258/2000 Coll.). This issue was addressed by a question in the questionnaire, which was related to the best decontamination method that nurses would use for various items. $83.2 \%$ of nurses correctly stated disinfection as the highest degree of decontamination of electrocardiograph leads. However, in the case of the bronchoscope, only $1 / 3$ of the nurses correctly chose the higher degree of disinfection, and in the case of the laryngoscopic spoon, even less than $1 / 3$ of the respondents correctly chose the twostage disinfection. Regarding surgical forceps, $93.5 \%$ of nurses correctly chose sterilization. The method of decontamination affects the resulting efficiency of safe use and ensures the requirements for quality and safe care. It is also necessary to say that incorrectly performed decontamination can also damage a disinfected object (World Health Organization, 2016). However, even in this regard, it is important to realize that an improperly determined method of decontamination is a crucial factor in minimizing harm to the patient when using medical devices.

One of the basic aspects is the use of a suitable disinfectant and respecting its prescribed exposure time (World Health Organization, 2016). This research has shown that nurses may have trouble interpreting the range of effectiveness that is indicated by letters on the packaging of disinfectants. The nurses were asked about the significance of the designation of the effectiveness range $\mathrm{A}, \mathrm{B}$, and $\mathrm{C}$. Only half of the nurses answered this question correctly, i.e., that it has a bactericidal, virucidal, and sporicidal effectiveness. The result could also be influenced by the fact that $41.9 \%$ of nurses have been in practice for 21 years or more, and this may not be sufficiently mentioned in the training. It is advisable to recommend that this information be included in disinfection regulations.

The preparation of the disinfectant solution is essential. The respondents were asked to indicate the quantity of water and disinfectant they would use to prepare 8 litres of $0.5 \%$ solution. The research showed that $2 / 3$ of nurses had knowledge of dilution. Most of the incorrect answers were represented by the N/A option. However, dilution of disinfection is an essential component for achieving the expected effect, as stronger solutions may not be more effective, and conversely, preparation of higher concentrations may lead to damaging the disinfected material (World Health Organization, 2016). Research in Ethiopia found that $87.9 \%$ of nurses had knowledge of how to prepare a disinfectant solution of adequate concentration (Sahiledengle, 2019). On the contrary, the question of how the respondents would proceed when diluting a disinfectant solution received a slightly more positive answer The research found that $79.9 \%$ of respondents would first correctly fill the container with water and then add a disinfectant. Another factor influencing the disinfection is the exposure time. It was found that less than half of the respondents would adhere to the prescribed exposure time of the selected disinfectant that is often used in clinical practice. The control question determined whether the respondents adhered to the recommended exposure time. $71.2 \%$ of respondents stated that they did and $23.9 \%$ of respondents almost always adhered to the exposure time. The respondent may have chosen this option because, in clinical practice, it may be problematic to adhere to the actual exposure time (Sattar, 2016). It is important to state that the exposure time is always related to a specific disinfectant. For its effective use, it is important to follow the manufacturer's instructions and the regulations of the health service provider.
Nurses' knowledge of disinfection is the basis for decontamination of high-touch objects and surfaces. However, in practice, disinfection itself is very often underestimated and medical professionals often do not realize that these objects and areas can be a possible source of pathogen spread of healthcare-associated infections (Donskey, 2019). Available studies also found that only $49.1 \%$ of nurses have acceptable decontamination practice (Sahiledengle, 2019). We can say that less than $40 \%$ of objects and areas in the patient zone are decontaminated in accordance with current recommendations (Mann et al., 2014).

The results of the research show that it is necessary to pay constant attention to this issue. In particular, it is important (not only in relation to lifelong learning) to continuously address the increase of knowledge of nurses through training. Training is a very effective source of the latest knowledge on the prevention and control of healthcare-associated infections (Luebbert and Chinnes, 2015). This is a fundamental aspect for the development of qualified professionals and adherence to hygienic and epidemiological principles (Gallagher, 2014). An effective option is simulation teaching; a method which helps to acquire knowledge, skills, and attitudes, has a positive effect on the provision of medical care and can be implemented in relation to the issue of decontamination (Motola et al., 2013). Currently, another possible aspect is the use of antimicrobial surfaces, which are gaining more attention for setting strategies regarding healthcare-associated infections. One possibility is nanomaterials, which represent new ways of designing effective antimicrobial surfaces (Hasan and Chatterjee, 2015). The knowledge of decontamination is one of the key elements for the daily provision of quality and safe nursing care.

\section{Conclusions}

Prevention of healthcare-associated infections remains a topical issue. One of the main components of this issue is the decontamination of reusable items and surfaces. Inadequate mechanical cleaning and chemical disinfection of high-touch reusable items and surfaces can lead to the transmission and subsequent development of healthcare-associated infections. Part of the implementation of each nursing intervention is the knowledge that can influence the actual implementation of the activity. This research has shown that nurses are aware of the reason for performing mechanical cleaning or the procedure of diluting disinfectant solutions, but in some areas the knowledge is problematic. For this reason, it is necessary to continuously implement training regarding the importance of disinfection, preparation of disinfection solutions, and disinfection procedure - using new teaching possibilities, including simulation methods, e-learning portals, etc., or reflex discussions. It is also necessary to look for other alternative options for establishing effective principles for the removal of microorganisms with the new option of treating surfaces with nanomaterials with antimicrobial properties.

\section{Ethical aspects and conflict of interests}

The authors declare that this study contains no conflict of interest and that the ethical aspects of the research have been observed. The research plan was approved by a health service provider. Respondents were informed about the purpose of the research and agreed to their inclusion in it.

\section{Acknowledgements}

The authors would like to thank the selected hospital and respondents for participating in the research. 


\section{Znalosti sester o dezinfekci opakovaně použivaných předmětů a ploch v klinické praxi}

\section{Souhrn}

Úvod: Provádění dezinfekce opakovaně používaných high touch předmětů a ploch patří k významným aspektům prevence infekcí spojených se zdravotní péčí a také pro kvalitní a bezpečné poskytování zdravotních služeb. Sestry by měly mít znalosti o postupu provedení mechanické očisty a dezinfekce, dezinfekčních prostředcích, včetně spektra účinnosti, př́ipravě a způsobu aplikace dezinfekčních prostředků.

Design: Průřezový kvantitativní výzkum pomocí dotazníku.

Metody: Kvantitativním výzkumem s využitím techniky dotazníku byly zjištovány znalosti sester o zásadách provedení mechanické očisty a dezinfekce opakovaně používaných nekritických předmětů a ploch v klinické praxi. Výzkumný soubor tvořilo 184 sester ve vybrané nemocnici krajského typu v České republice. Výzkumu se zúčastnili respondenti ze standardních interních a chirurgických oddělení. Data byla analyzována pomocí popisné statistiky a statistického testu.

Výsledek: V rámci výzkumu bylo zjištěno, že $68,5 \%$ sester zná postup dekontaminace pracovní plochy bez přítomnosti biologického materiálu a 51,1 \% sester zná postup dekontaminace pracovního podnosu s př́tomností biologického materiálu. O interpretaci spektra účinnosti dezinfekčních prostředků má znalosti 51,1 \% sester a 65,2 \% sester má znalosti o ředění dezinfekčního roztoku. Závěr: Na základě výsledků výzkumu lze uvést, že sestry mají v některých oblastech adekvátní znalosti, ovšem i tak je nutné zajistit pravidelné školení o zásadách provedení dekontaminace vybraných předmětů a ploch používaných v ošetřovatelské praxi. Infekce spojené se zdravotní péčí lze ovlivnit dodržováním nastavených hygienicko-epidemiologických zásad.

Klíčová slova: dezinfekce; klinická praxe; ošetřovatelství; sestra; znalost

\section{References}

1. Act No. 258/2000 Coll. on the Protection of Public Health and on the Amendment of Certain Related Acts. In: Collection of laws of the Czech Republic 84/2000.

2. Act No. 55/2011 Coll. on the activities of health professionals and other professionals. In: Collection of laws of the Czech Republic 20/2011.

3. Act No. 306/2012 Coll. on the conditions for the prevention of the occurrence and spread of infectious diseases and on hygienic requirements for the operation of medical facilities and social care institutions. In: Collection of laws of the Czech Republic 109/2012.

4. Donskey CJ (2019). Beyond high-touch surfaces: Portable equipment and floors as potential sources of transmission of health care-associated pathogens. Am J Infect Control 47(2019): 90-95. DOI: 10.1016/j.ajic.2019.03.017.

5. Gallagher R (2014). The Role of the Nurse in Decontamination. In: Walker JT. Decontamination in Hospitals and Healthcare. Philadelphia: Woodhead, pp. 142-165.

6. Hasan J, Chatterjee K (2015). Recent Advances in Engineering Topography Mediated Antibacterial Surfaces. Nanoscale 7(2015): 15568-15575. DOI: 10.1039/C5NR04156B.

7. Hedlová D, Jindrák V, Malý M (2014). Postupy prevence a kontroly infekcí. In: Jindrák $\mathrm{V}$, et al. Antibiotická politika a prevence infekcí v nemocnici. Praha: Mladá fronta, pp. 549-603.

8. Krause M, Dolák F (2020). Rizikové předměty a plochy z hlediska přenosu infekcí při poskytování zdravotní péče. Prakt Lék 100(4): 203-206.

9. Link T, Kleiner C, Mancuso MP, Dziadkowiec O, HalversonCarpenter K (2016). Determining high-touch areas in the operating room with levels of contamination. Am J Infect Control 44(11): 1350-1355. DOI: 10.1016/j.ajic.2016.03.013.

10. Luebbert P, Chinnes L (2015). Preventing Healthcare-Associated Infections. Brentwood: $\mathrm{HCPr}$, p. 180.

11. Mann EE, Manna D, Mettetal MR, May RM, Dannemiller EM, Chung KK, et al. (2014). Surface micropattern limits bacterial contamination. Antimicrob Resist Infect Control 3(28): 1-8. DOI: 10.1186/2047-2994-3-28

12. Marx D, Vlček F (2013). Akreditační standardy pro nemocnice. Praha: Tigis

13. Matoušková I, Jurásková S (2017). Hygienicko-epidemiologický režim zubní a ortodontické ordinace. Praha: Grada, p. 128.
14. Motola I, Devine LA, Chung HS, Sullivan JE, Issenberg SB (2013). Simulation in healthcare education: a best evidence practical guide. AMEE Guide No. 82. Med Teach 35(10): 1511-1530. DOI: 10.3109/0142159X.2013.818632.

15. Nightingale F (1859). Notes on Nursing: What it is, and what it is not. Pennsylvania: J. B. Lippincott.

16. Royal College of Nursing (2017). Essential Practice for Infection Prevention and Control: Guidance for nursing staff. London: Royal College of Nursing, p. 31.

17. Russotto V, Cortegiani A, Raineri SM, Giarratano A (2015). Bacterial contamination of inanimate surfaces and equipment in the intensive care unit. J Intensive Care 54(3): 1-8. DOI: 10.1186/s40560-015-0120-5.

18. Sahiledengle B (2019). Decontamination of patient equipment: nurses' self-reported decontamination practice in hospitals of southeast Ethiopia. BMC Res Notes 12(392): 1-7. DOI: 10.1186/s13104-019-4427-5.

19. Sattar S (2016). Cleaning, Disinfection, and Sterilisation. Portadown: International Federation of Infection Control, p. 12.

20. Schmidt MG, Dessauer B, Benavente C, Benadof D, Cifuentes P, Elgueta A, et al. (2016). Copper surfaces are associated with significantly lower concentrations of bacteria on selected surfaces within a pediatric intensive care unit. Am J Infect Control 44(2): 203-209. DOI: 10.1016/j.ajic.2015.09.008.

21. Suleyman G, Alangaden G, Bardossy AC (2018). The Role of Environmental Contamination in the Transmission of Nosocomial Pathogens and Healthcare-Associated Infections. Curr Infect Dis Rep 20(6): 1-12. DOI: 10.1007/s11908-0180620-2.

22. Wilson AJ, Nayak S (2016). Disinfection, Sterilization and Disposables. Anaesth Intensive Care Med 17(10): 475-479. DOI: 10.1016/j.mpaic.2016.07.002.

23. World Health Organization (2016). Decontamination and Reprocessing of medical devices for health-care facilities. Geneva: World Health Organization, p. 118.

24. World Health Organization (2018a). Global Guidelines for the Prevention of Surgical Site Infection. Geneva: World Health Organization, p. 184.

25. World Health Organization (2018b). Prevention and Control of Healthcare-Associated Infections. Basic Recommendations. Washington: Pan American Health Organization, p. 184.

26. Yang D, Lin L, Guo P, Zhang W, He X, Huang Q, et al. (2017). Flashlight Contamination and Effectiveness of two Disinfectants in a Stomatology Hospital. Int J Nurs Sci 4(2): 169-172. DOI: 10.1016/j.ijnss.2017.03.008. 